Professor Leonardo BADEA, PhD

E-mail: leobadea@yahoo.com

The Romanian Financial Supervisory Authority

Valahia University of Târgoviste

Associate Professor Iulian PANAIT, PhD

E-mail: iulian.panait@gmail.com

The Romanian Financial Supervisory Authority

Hyperion University of Bucharest

Professor Adela SOCOL, PhD

E-mail: adela_socol@yahoo.com

"1 Decembrie 1918" University of Alba Iulia

Associate Professor Andreea Daniela MORARU

Ovidius University of Constanta

E-mail: moraru.ad@gmail.com

\title{
SENTIMENT, PERCEPTION AND POLICY DETERMINANTS OF FOREIGN DIRECT INVESTMENT TO EUROPEAN DEVELOPING COUNTRIES
}

Abstract: In this paper we have investigated the impact on FDI of different factors, at quarterly and annual frequency, as reflected by economic variables (GDP, labour cost), market variables indicating country risk perception (equity markets volatility, CDS), economic sentiment and confidence indicators (computed by the European Commission) and investor perception indicators (various measures of transparency, public sector governance and accountability, political stability, law enforcement and control of corruption computed by the World Bank). Our analysis was done for ten developing European economies, using a stepwise panel regression approach and a one-lag panel VAR. Our main results confirm the effect of GDP and labour cost on Net FDI that were also identified previously. Also, we found a significant influence from CDS prices, which is aligned with previous findings on the influence of credit ratings. At the same time, our results showed a statistically significant influence on FDI from Voice and Accountability, Government Effectiveness, Regulatory Quality and Control of Corruption.

Keywords: Foreign Direct Investment, economic sentiment indicators, market perceptions, government policies, VAR.

JEL Classification: C23; E71; F21

\section{Introduction}

The interest of the academic communities and of the business environment in studying the global trend and pattern of foreign direct investment has been largely manifested throughout the last years and is especially based on the public recognition of the positive effect 
of foreign direct investment on the development of economies. The World Bank's definition of foreign direct investment presents it as a category of cross-border investment associated with a resident in one economy having control or a significant degree of influence on the management of an enterprise that resides in another economy. This approach is in line with OECD Benchmark Definition of Foreign Direct Investment (1996), which recommends that a direct investment enterprise be defined as an incorporated or unincorporated enterprise in which a foreign investor owns 10 percent or more of the ordinary shares or voting power of an incorporated enterprise or the equivalent of an unincorporated enterprise.

In many European developing countries that run significant current account deficits, foreign direct investment is of particular importance not only because it helps finance this gap but also because it represents a major support for the adoption of modern technologies and for increasing the overall productivity and competitiveness of the economy, thus contributing to the real convergence.

Foreign Direct Investment plays a key role for national economies, especially in emerging economies, as they are from Central and Eastern European countries that are significantly transforming into developed economies. FDI generates transfer of financial and human capital, resources and new technologies, knowledge and skills of employees from developed countries to emerging ones. Also, FDI stimulates financial markets in host countries, supports trade, decreases the level of unemployment and, in general, contributes to economic growth. Other major benefits of FDI for emerging countries can be identified in its quality of alternative sources of financing national economies, such as improving managerial practices, restructuring of local institutions, or development of research in universities. However, the mechanisms and factors that contribute to the FDI's evolution are not yet fully clarified as a result of the complex nature of FDI's determinants and differences between countries.

The main assertion of the paper is that there is a direct correlation between Foreign Direct Investment FDI and key economic indicators such as Gross Domestic Product GDP and Labor Cost. Simultaneously, we investigate the link between FDI and some high frequency market perception indicators such as volatility of Currency or CDS Price for Sovereign Debt. Also, we overcame the classical approach of FDI economic factors and identified a number of variables that could be responsible for the FDI behaviour. These less studied determinants of the FDI concern the governance indicators published by the World Bank (Voice and Accountability Indicator, Political Stability and No Violence Indicator, Government Effectiveness Indicator, Regulatory Quality Indicator, Rule of Law Indicator), the moral and psychological effects of corruption (Control of Corruption Indicator) or few confidence indicators (Economic Sentiment Indicator of the European Commission, Consumer Confidence Indicator or Industrial Confidence Indicator).

Our choice of possible factors of influence was aimed at combining pure quantitative economic and market factors with more qualitative factors that reflect sentiment / perception of agents within the economy and investors from outside. We were also interested to see if and how the link between these factors and FDI is manifesting both on the short and on the long term, and for that reason we used both quarterly data and annual data.

The paper is structured as follows: an overview of the literature in the area, the research direction, data and methodology, the developing of the panel regression for 10 countries (2010 
Sentiment, Perception and Policy Determinants of Foreign Direct Investment to European Developing Countries

- 2017) in order to analyse the interdependency between Foreign Direct Investment FDI and some determinants (for the annual data the Worldwide Governance Indicators issued by the World Bank, GDP, Labor Cost Index, CDS Prices for the Sovereign Debt, and Volatility of Local Currency against the US dollar while for quarter data the Seasonality-Adjusted Economic Sentiment Indicator of the European Commission, the Seasonality-Adjusted Industrial Confidence Indicator, the Seasonality-Adjusted Services Confidence Indicator, the Seasonality-Adjusted Consumer Confidence Indicator, the Seasonality-Adjusted GDP, the Labor Cost Index, the CDS Price for Sovereign Debt and a Measure of the Quarterly Volatility of the Local Currency versus the US dollar). The final part contains results and general conclusions.

\section{Literature Review}

Contemporary general economic assumptions reveal that there is a relationship between Foreign Direct Investment FDI and many macroeconomic determinants. The importance of FDI for the national economies has been widely recognized for years by both practitioners and academics. Studies on relation between FDI and many variables have been published during the last years. A systematic literature review of the empirical studies on FDI determinants does not represent a main purpose of our approach. We used that branches of the relevant literature on FDI macroeconomic studies that touch on the variables that could explain FDI behaviour and we were especially preoccupied to study significant dedicated literature on FDI determinants that we consider variables in our study.

Specific macroeconomic variables have proven significant as FDI's determinants in some studies (eg GDP, Inflation, Unemployment Rate, Labor Cost etc.), but the aspects of the qualitative nature of national economies have not been studied to the same extent. Empirical relationship between FDI and qualitative indicators of moral or psychological perception of governance in an economy is unclear.

Noyan and Zortuk (Aydin and Zortuk, 2014) suggested that transition economies see FDIs as a fundamental economic factor for achieving economic growth. They measured the efficiency of FDI inflows for 12 countries that separated from USSR based on Fuzzy DEA Data Envelopment Analysis, a non-parametric relative efficiency method for comparing units for 2011. The following ranking was obtained: Russia, Kazakhstan, Ukraine, Azerbaijan, Tajikistan, Lithuania, Georgia, Armenia, Kyrgyz Republic, Moldova, Estonia, and Latvia.

An important contribution in examining the relationship between institutional Kaufmann (Kaufmann et al., 1999) variables (Voice and Accountability, Political Stability, Government Effectiveness, Regulatory Quality, Control of Corruption, Rule of Law, Political Stability and Freedom, Government Efficiency) and FDI stocks belongs to Daude and Stein (Daude and Stein, 2007), that developed panel data analysis using dataset of FDI from 34 countries, most of them developed to 152 host countries from 1982 until 2002. The authors found that the quality of institutions has positive effects on FDI, but not all dimensions of the institutional framework have the same direct importance for foreign investors' investment decisions (regulatory framework and the effectiveness of the government are the most sensitive aspects while there is little evidence of any significant impact of political instability and violence on FDI or no evidence of a direct effect of civil liberties and political violence). 
Similar research (Kurecic and Kokotovic, 2017) is concentrating on the study of the relevance of the Political Stability to FDI in three panels (11 very small economies Seychelles, Guinea-Bissau, Lesotho, Dominica, Grenada, St. Lucia, Burundi, Vanuatu, St. Kitts and Nevis, St. Vincent and the Grenadines, Antigua and Barbuda; 5 well-developed and political stable economies with highly positive FDI net inflows - Australia, Canada, France, The United Kingdom, The United States; 4 economies with political violence or targeted by the terrorist attacks - Mexico, Israel, The Russian Federation, Turkey) through Vector Autoregressive VAR and Autoregressive Distributed Lag ARDL model. The findings show that political stability is not a crucial factor in determining FDI inflows in highly developed or large, emerging economies studied. The authors proved that political stability is only relevant to FDI in the panel of smallest economies, while there is no such causality in larger economies. Based upon the VAR analysis, they found that the relationship between political stability and FDI is relevant both in the short term and in the long term for the small economies in first panel, while they found limited evidence of relevance of political stability towards increasing FDI in the short term for second or third panels.

The effect of governance indicators (Political Stability, Control of Corruption, Rule of Law, Regularity Quality, Voice and Accountability and Government Effectiveness) on FDI flows was studied by Gangi and Abdulrazak (Gangi and Abdulrazak, 2012). The authors developed a panel regression model on data from 50 African countries for the period 1996 to 2010. The results obtained through fixed and random effects indicate that out of the six World Bank's governance indicators, three are statistically significant: Voice and Accountability, Government Effectiveness and Rule of Law.

The relationship between FDI and domestic investment induced by corruption and human capital was studied by Delgado and McCloud (Delgado and McCloud, 2017), that found results contrary to the existing literature: controlling for corruption and human capital, they show that inbound FDI had significant heterogeneous complementary effects on domestic investment, whereas outbound FDI has fluid effects on domestic investment. They sample consists in 137 developed and developing countries over the period 1984-2010.

A linear regression model was developed in order to study Romania's situation regarding the four FDI's determinants between 1991 and 2006: Market size and potential, Reform progress, Business liberalization, and Labor cost (Birsan and Buiga, 2009). They concluded that the only way of overcoming the deficit and the increased labor cost pressure is increase in productivity.

Literature on impacts of volatility of currency on FDI confirms that the impacts of the exchange rate volatility on FDI are positive and statistically significant, according to Kiyota and Urata (2004). They developed a regression analysis of annual FDI from Japan to its partner countries between 1990 and 2000 and found that the depreciation of the host country currency attracts FDI while large volatility in real exchange rates discourages FDI.

Some authors (Wang and Hung-Pin, 2017) investigated the causal relationship between DI Domestic Investment and OFDI Outward Foreign Direct Investment using data from 1990 to 2011 for 9 newly industrialized Asian countries: China, Indonesia, Japan, Malaysia, Philippines, Singapore, South Korea, Taiwan, and Thailand. Results suggest a non-uniform causal relationship between DI and OFDI among countries (short-run unidirectional causality 
Sentiment, Perception and Policy Determinants of Foreign Direct Investment to European Developing Countries

running from DI to OFDI - China, Japan and South Korea; long-run and strong unidirectional causality running from OFDI to DI - Singapore and Taiwan and form DI to OFDI in China. The causality between DI and OFDI in Indonesia, Malaysia, Philippines, and Thailand was not detected).

Mutascu and Fleischer (Mutascu and Fleischer, 2010) studied the relationship between FDI and Wages in Romania, using an Unrestricted Vector Autoregressive Model VAR for the period 2002-2009. Their results adhere to the relevant literature on the relationship FDI wages and the authors have invoked the theory according to which the two variables have a one-on-one influence. The study explains that the impact of the wages on the FDI is temporally sinuous in short term and the impact of the FDI on the wages is not uniform during a year.

Some authors (Asghar et. al, 2012) examined the relationship between FDI and economic growth by applying advanced panel techniques. They confirm the positive impact of FDI on economic growth, using heterogeneous panel for the period 1983-2008 using FMOLS Fully Modified Ordinary Least Squares estimates. Johansen cointegration analysis confirms the existence of a long-run relationship only in the case of India, Sri Lanka, Maldives, Thailand, China and Philippine.

Also, the relationship between FDI and economic growth was explored by Baklouti and Boujelbene (Baklouti and Boujelbene, 2016), that have studied the FDI determinants - Real GDP, Inflation , Energy and Institutional quality - in 12 countries from MENA region using GMM method. They found that FDI variable (measured by foreign direct investment, net inflows (\% of GDP)) has a positive and significant impact on real GDP.

Simionescu (Simionescu, 2017) studied similar countries as development level Bulgaria and Romania - between 2008 and 2015 for some relevant macroeconomic determinants for FDI using a Bayesian approach (FDI as percent of GDP, real GDP rate, unemployment rate, inflation rate, real interest rate, real effective exchange rate index $(2010=100)$ and money demand (M2) as percent of GDP). The results prove that the increase in real GDP attracted more foreign investors during the recent economic crisis. Inflation had the biggest impact on foreign investors' decisions in Bulgaria, while for Romania its influence on FDI is not significant. Higher unemployment rates in Romania attracted more investors searching for cheaper labour force, while in Bulgaria even if the unemployment rate grew, the foreign investors were not encouraged by this reason to invest in Bulgaria. A negative relationship was observed between FDI and real interest rate. Real effective exchange rate index $(2010=100)$ and money demand (M2) had a positive, but insignificant effect on FDI in Bulgaria. In Romania, money demand $\mathrm{M} 2$, inflation rate and real effective exchange rate index $(2010=100)$ had a positive, but insignificant effect on FDI.

EU-28 states were studied by Simionescu (Simionescu, 2016) in order to find relation between FDI and GDP rate at two levels - panel data approach and an individual analysis for each country based on Bayesian linear regressions and cluster analysis. The author concludes that at an aggregate level, there was a positive and bidirectional relationship between GDP rate and FDI in the period from 2008 to 2014. Since 2008, in the context of world crisis, FDI decreased fast, but also the economic growth of the EU countries was negatively affected. Actual FDI had a positive, but very slow impact on actual economic growth in the EU-28 countries during 2008-2014. 
Relationship between FDI and trade was investigated by Simionescu (Simionescu, 2014) in G7 countries using panel data approach over the period 2002-2013. Only short run causality between FDI and exports and FDI and imports was proved. Also, short run causality in both senses was observed for FDI and trade in G7 countries.

A paper on BRICS economies (Brazil, Russia, India, China and South Africa) belongs to Labes (Labes, 2015), that analysed FDI for a time series from 1992-2012 taking in consideration the following variables: Trade Openness, GDP per capita, Population, Exchange Rate and Human Capital. The results indicate that the most significant determinants of FDI Inflows are Trade Openness, GDP per capita and Exchange Rate.

\section{Data and Methodology}

Our investigation for the relevant group of factors that influence the dynamics of the Foreign Direct Investments for group of small to medium CEE developing economies (10 countries) is two-fold. On the one hand, we collected quarter data on: Foreign Direct Investments, the Seasonality-Adjusted Economic Sentiment Indicator of the European Commission (Ec. Sent. - variable 1 in our charts), the Seasonality-Adjusted Industrial Confidence Indicator (Ind. Confid. - variable 2), the Seasonality-Adjusted Services Confidence Indicator (Serv. Confid. - variable 3), the Seasonality-Adjusted Consumer Confidence Indicator (Cons. Confid. - variable 4), the Seasonality-Adjusted GDP (GDP -variable 5), the Labor Cost Index (Labor Cost - variable 6), the CDS Price for Sovereign Debt (CDS - variable 7) and a Measure of the Quarterly Volatility of the Local Currency versus the US dollar (Volatility - variable 8).

On the other hand, we used data with annual frequency for the following variables: Foreign Direct Investments, a set of indicators computed by the World Bank: Voice and Accountability Indicator (Voice Acc. - variable 1), Political Stability and No Violence Indicator (Pol. Stab. - variable 2), Government Effectiveness Indicator (Gov. Effect. - variable 3), Regulatory Quality Indicator (Regul. Qual. - variable 4), Rule of Law Indicator (Rule Law variable 5) and Control of Corruption Indicator (Corrup. - variable 6), GDP (variable 7), Labor Cost Index (Labor Cost - variable 8), CDS Prices for the Sovereign Debt (CDS - variable 9) and Volatility of Local Currency against the US dollar (Volatility - variable 10).

Data was collected from Datastream, Eurostat and Bloomberg.

These two groups of data were collected for the following countries: Bulgaria, The Czech Republic, Estonia, Hungary, Lithuania, Latvia, Poland, Romania, Slovenia, and Slovakia. The analysis on quarterly data covered twenty-nine intervals from the first quarter of 2010 until the first quarter of 2017, while the yearly data covered fifteen intervals from 2002 until 2016.

The research used data on 10 mentioned countries, classified as emerging markets from Central and Eastern Europe. Our comparative perspective of emerging economies is based on a presumed high degree of economic synchronization between the selected countries. We suppose that these economies presented a similar context of economic development about 30 years ago and that they had resembling experiences as transitional economies. These emerging countries are selected because they liberalized their economies since the ' 90 and have undergone considerable and drastic changes from a communist economy to an open one (a 
Sentiment, Perception and Policy Determinants of Foreign Direct Investment to European Developing Countries

result of the national revolutions or of the dissolution of the Soviet Union).

Our analysis consisted in the realization of a stepwise panel regression in which we tried to identify the set of factors that influence the dynamics of the Foreign Direct Investments FDI as the main dependent variable. The other variables were added to the analysis in an incremental manner so that all combinations had been taken into account. This analysis was performed both for the quarter and annual data and the results reflect our findings for each panel regression.

Figure 1: Presentation of cross-distributions of quarterly data: factors stacked across countries

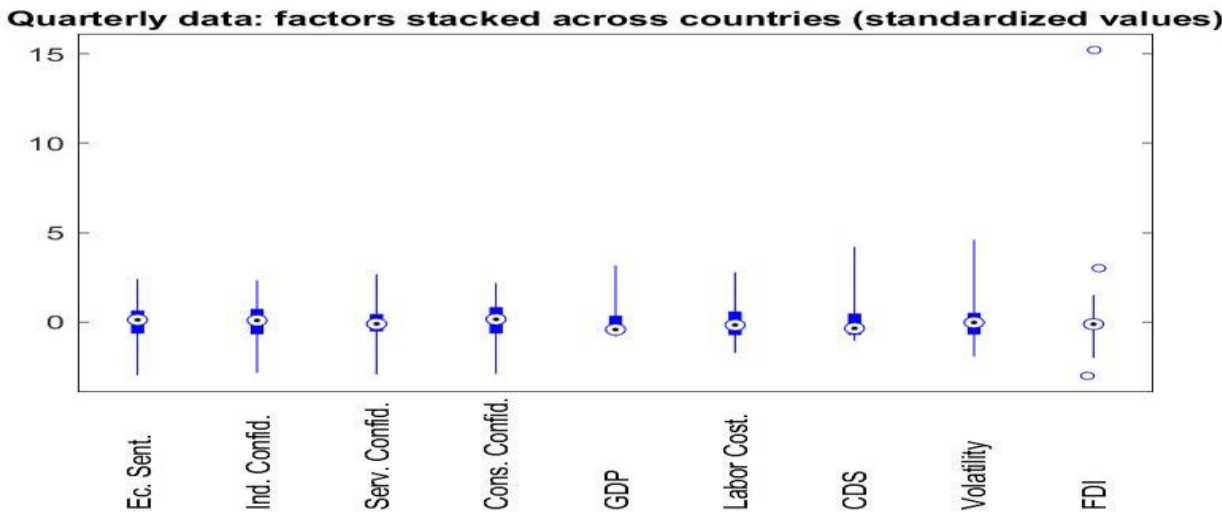

Source: Datastream, Eurostat and Bloomberg, author's calculations

Figure 2: Presentation of cross-distributions of quarterly data: countries stacked across factors

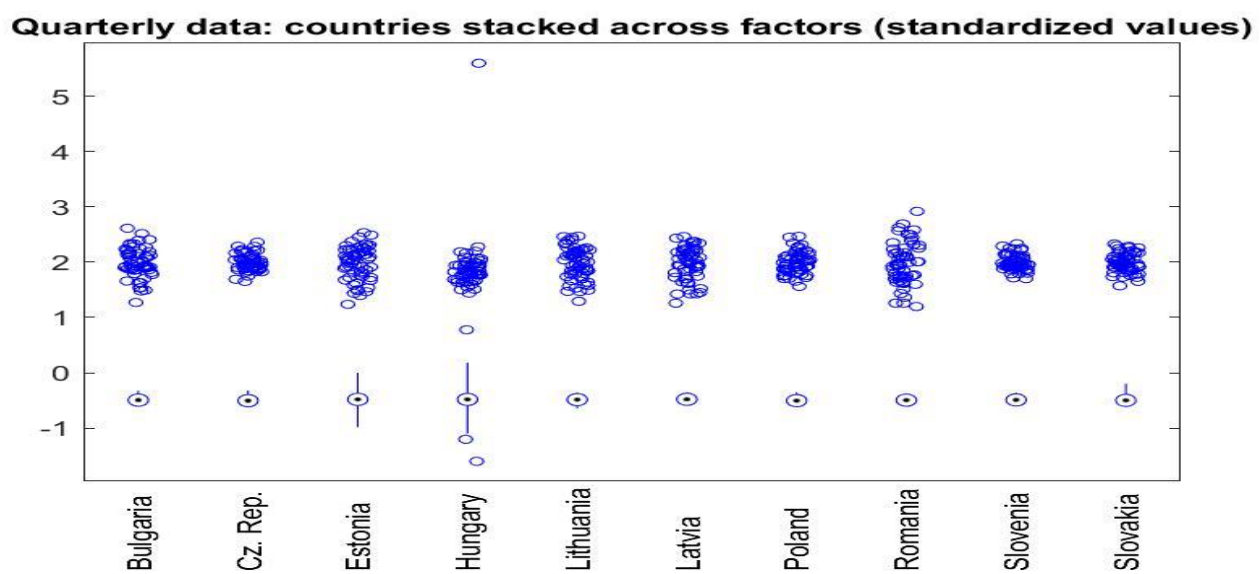

Source: Datastream, Eurostat and Bloomberg, author's calculations 
Leonardo Badea, Iulian Panait, Adela Socol, Andreea Daniela Moraru

Figure 3: Presentation of cross-distributions of annual data: factors stacked across countries

Annual data: factors stacked across countries (standardized values)

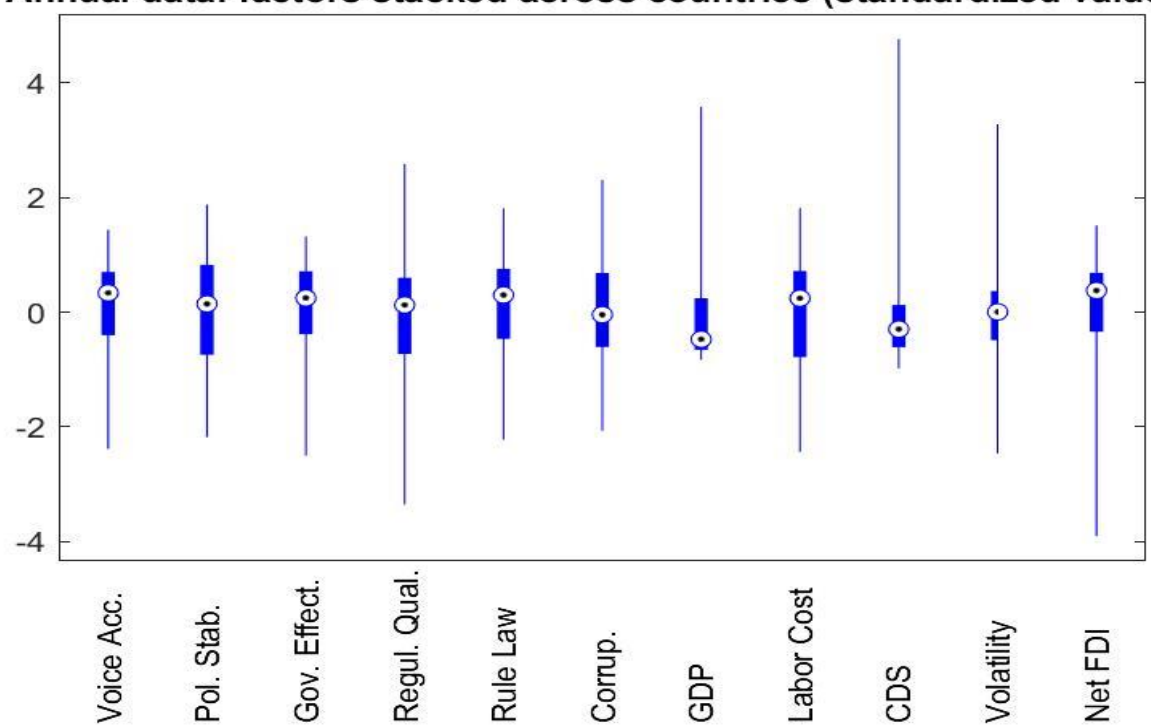

Source: Datastream, Eurostat and Bloomberg, author's calculations

Figure 4: Presentation of cross-distributions of annual data: countries stacked across factors

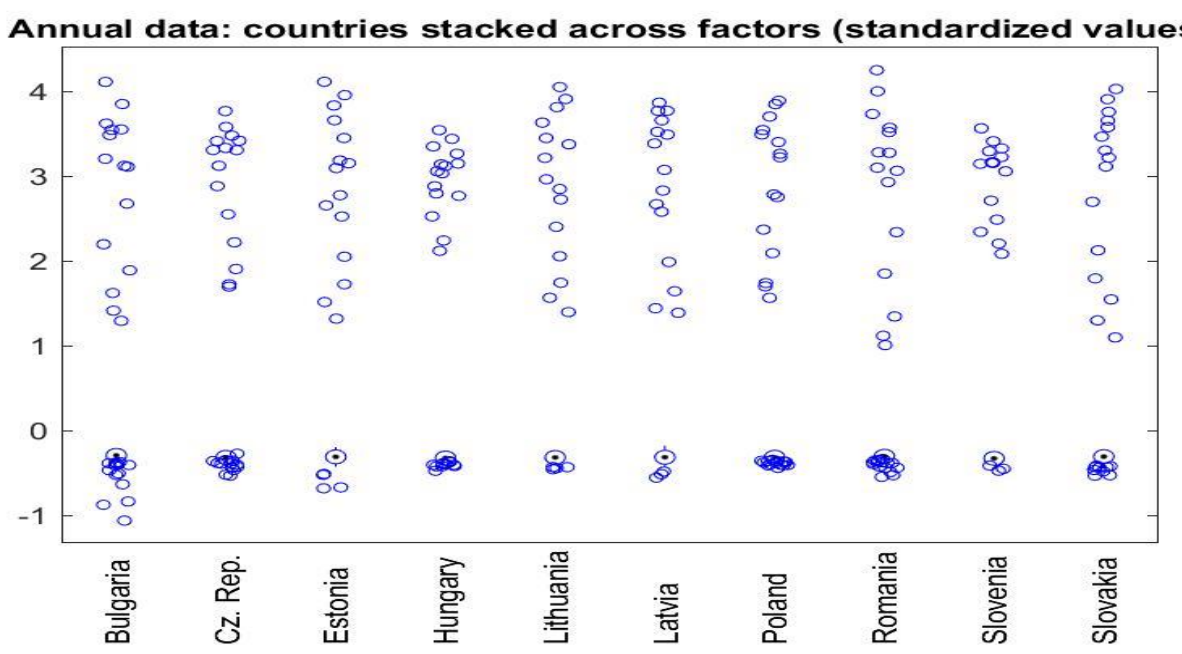

Source: Datastream, Eurostat and Bloomberg, author's calculations 
Sentiment, Perception and Policy Determinants of Foreign Direct Investment to European Developing Countries

Considering the results obtained from the panel regressions, we decided to apply a vector autoregression (VAR) analysis on the factors at annual frequency because in their case we found a greater number of significant coefficients across all specifications. We used a one-lag panel VAR specification (with stacked data) with the aim to investigate possible codependence between the variables.

\section{Results}

As mentioned in the previous section, our analysis consisted in the development of an algorithm that estimates all the possible panel regression specifications, given the data in our sample. We consequently performed the following types of specifications: Fixed Effects, Robust Fixed Effects and Random Effects on level data and Random Effects on first differences. Each specification was performed 512 times for the annual data and 256 times for the quarterly data.

Under this approach, we were able to determine the percentage of situations in which the explanatory variables provided significant coefficients. The distributions of p-values are presented in the following boxplot representations for each specification (the distribution of $\mathrm{p}$ values is also exhibited in table format in the appendix).

For the quarterly data, we notice that low levels of p-values are encountered only in very isolated situations. The Random Effects in differences provide the best specifications with Economic Sentiment and CDS providing most significant coefficients.

From a different perspective, the annual data reveals more significant situations as the distributions of $p$-values lie on the lower end for all specifications. We notice the most significant coefficients in the case of the Fixed Effects in levels and the Random Effects in differences. We can also conclude that Voice and Accountability and Rule of Law show situations with a statistically significant influence on FDI.

Figure 5: Distribution of $p$-values for the analysis on quarterly data
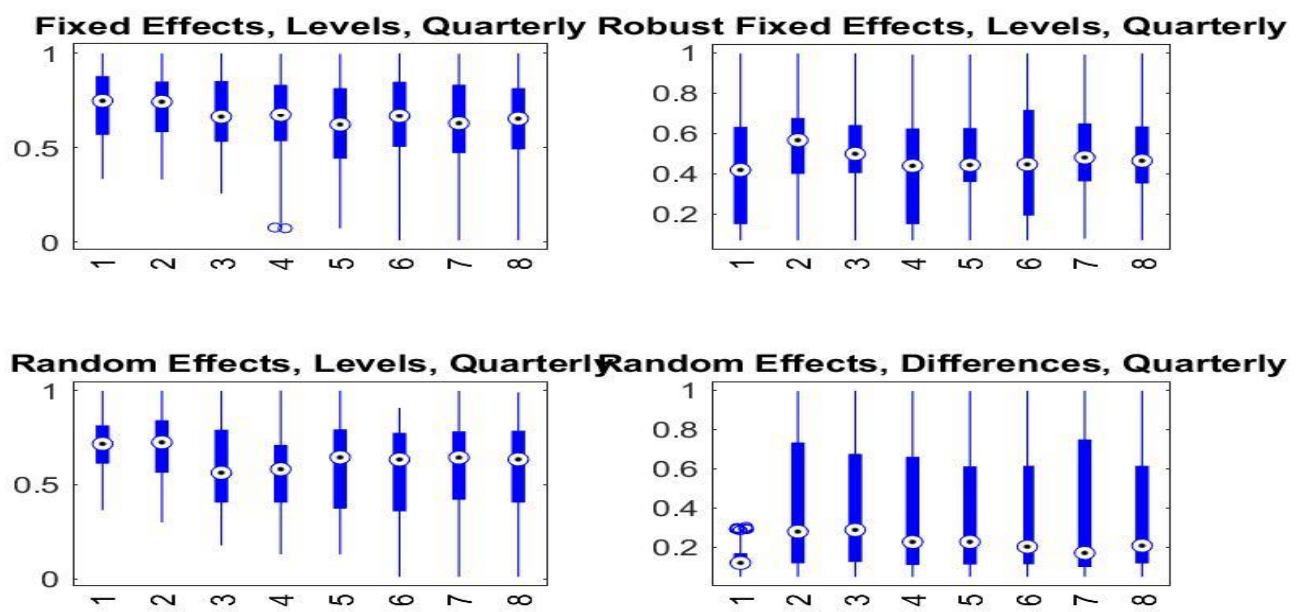
Figure 6: Distribution of p-values for the analysis on annual data
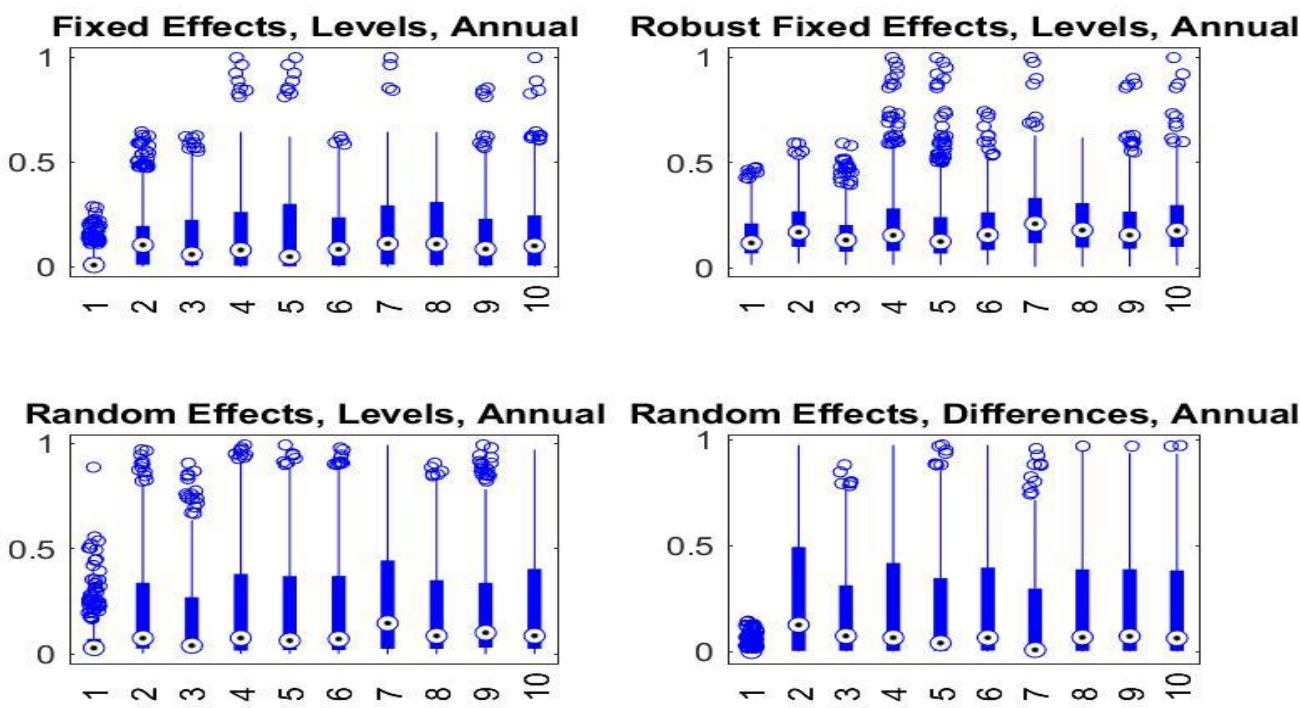

Given the fact that the annual data provided several significant coefficients across all specifications, we also employed a one-lag panel VAR specification to estimate the existing co-dependence in the set of variables. We decided to use the Foreign Direct Investments, the GDP, the Labor Cost Index, the CDS and the Volatility of exchange rate with USD as endogenous variables, while the rest were considered as exogenous. Our results are presented in the following table. Our main interest is to look for the effects on Net FDI, but effects on GDP, labor cost and CDS are also presented bellow for comparison.

Table 1. Estimation output from panel VAR on annual data

\begin{tabular}{|c|c|c|c|c|c|c|c|c|}
\hline & \multicolumn{4}{|c|}{ Net FDI } & \multicolumn{4}{|c|}{ GDP } \\
\hline & Coef. & STD. & Tstat & P-value & Coef. & STD. & Tstat & P-value \\
\hline Constant & -3169.20 & 1433.80 & -2.21 & $0.03 * *$ & 0.00 & 34371.00 & 0.00 & 1.00 \\
\hline FDInet - lag 1 & 0.15 & 0.08 & 1.83 & $0.07 *$ & -3.41 & 1.97 & -1.73 & $0.08 *$ \\
\hline GDP - lag 1 & -0.01 & 0.00 & -5.17 & $0.00 * * *$ & 0.84 & 0.06 & 13.80 & $0.00 * * *$ \\
\hline LaborCost - lag 1 & 23.22 & 8.80 & 2.64 & $0.01 * *$ & 87.88 & 210.95 & 0.42 & 0.68 \\
\hline CDS - lag 1 & 2.25 & 1.30 & 1.73 & $0.08 *$ & -13.27 & 31.19 & -0.43 & 0.67 \\
\hline Volatility - lag 1 & 0.00 & 50587.00 & 0.00 & 1.00 & 0.00 & 1212700.00 & 0.00 & 1.00 \\
\hline \multicolumn{9}{|l|}{ Exogenous } \\
\hline Voice and Accountability & -6818.70 & 2253.00 & -3.03 & $0.00 * * *$ & 0.00 & 54010.00 & 0.00 & 1.00 \\
\hline Voice and Accountability - lag 1 & -1052.00 & 1001.90 & -1.05 & 0.29 & 0.00 & 24016.00 & 0.00 & 1.00 \\
\hline Political Stability No Violence & 2008.60 & 1461.10 & 1.37 & 0.17 & 0.00 & 35026.00 & 0.00 & 1.00 \\
\hline $\begin{array}{l}\text { Political Stability No Violence - } \\
\text { lag } 1\end{array}$ & 1566.40 & 1672.20 & 0.94 & 0.35 & 0.00 & 40086.00 & 0.00 & 1.00 \\
\hline Government Effectiveness & -2788.10 & 1844.30 & -1.51 & 0.13 & 0.00 & 44211.00 & 0.00 & 1.00 \\
\hline $\begin{array}{l}\text { Government Effectiveness - lag } \\
1\end{array}$ & 2534.90 & 1472.30 & 1.72 & $0.09 *$ & 0.00 & 35294.00 & 0.00 & 1.00 \\
\hline Regulatory Quality & 1854.10 & 2453.10 & 0.76 & 0.45 & 0.00 & 58805.00 & 0.00 & 1.00 \\
\hline
\end{tabular}


Sentiment, Perception and Policy Determinants of Foreign Direct Investment to European Developing Countries

\begin{tabular}{|c|c|c|c|c|c|c|c|c|}
\hline Regulatory Quality - lag 1 & 3755.00 & 1041.90 & 3.60 & $0.00 * * *$ & 0.00 & 24977.00 & 0.00 & 1.00 \\
\hline Rule of Law & -962.38 & 1492.50 & -0.64 & 0.52 & 0.00 & 35779.00 & 0.00 & 1.00 \\
\hline Rule of Law - lag 1 & -126.40 & 1744.50 & -0.07 & 0.94 & 0.00 & 41819.00 & 0.00 & 1.00 \\
\hline Control of Corruption & 3422.60 & 1881.10 & 1.82 & $0.07 *$ & 0.00 & 45095.00 & 0.00 & 1.00 \\
\hline \multirow[t]{3}{*}{ Control of Corruption - lag 1} & -2398.30 & 1439.40 & -1.67 & 0.10 & 0.00 & 34505.00 & 0.00 & 1.00 \\
\hline & \multicolumn{4}{|c|}{ Labor Cost } & \multicolumn{4}{|c|}{ CDS } \\
\hline & Coef. & STD. & Tstat & P-value & Coef. & STD. & Tstat & P-value \\
\hline Constant & 22.91 & 9.91 & 2.31 & $0.02 * *$ & 4.95 & 96.18 & 0.05 & 0.96 \\
\hline FDInet - lag 1 & 0.00 & 0.00 & -1.94 & $0.05^{* *}$ & -0.01 & 0.01 & -0.92 & 0.36 \\
\hline GDP - lag 1 & 0.00 & 0.00 & -0.93 & 0.35 & 0.00 & 0.00 & -2.04 & 0.04 \\
\hline LaborCost - lag 1 & 0.84 & 0.06 & 13.85 & $0.00 * * *$ & 0.67 & 0.59 & 1.14 & 0.25 \\
\hline CDS - lag 1 & 0.01 & 0.01 & 0.61 & 0.54 & 0.34 & 0.09 & 3.89 & $0.00 * * *$ \\
\hline Volatility - lag 1 & -15.91 & 349.54 & -0.05 & 0.96 & $-\overline{2325.60}$ & 3393.50 & -0.69 & 0.49 \\
\hline \multicolumn{9}{|l|}{ Exogenous } \\
\hline Voice and Accountability & -81.92 & 15.57 & -5.26 & $0.00 * * *$ & -181.65 & 151.14 & -1.20 & 0.23 \\
\hline Voice and Accountability - lag 1 & -39.72 & 6.92 & -5.74 & $0.00 * * *$ & -84.49 & 67.21 & -1.26 & 0.21 \\
\hline Political Stability No Violence & 25.16 & 10.10 & 2.49 & $0.01 * * *$ & -128.81 & 98.02 & -1.31 & 0.19 \\
\hline $\begin{array}{l}\text { Political Stability No Violence - } \\
\text { lag } 1\end{array}$ & -0.95 & 11.55 & -0.08 & 0.93 & 109.42 & 112.17 & 0.98 & 0.33 \\
\hline Government Effectiveness & 48.27 & 12.74 & 3.79 & $0.00 * * *$ & 207.48 & 123.72 & 1.68 & $0.09 *$ \\
\hline $\begin{array}{l}\text { Government Effectiveness - lag } \\
1\end{array}$ & 7.56 & 10.17 & 0.74 & 0.46 & -144.60 & 98.77 & -1.46 & 0.14 \\
\hline Regulatory Quality & 59.38 & 16.95 & 3.50 & $0.00 * * *$ & 293.03 & 164.56 & 1.78 & $0.07 *$ \\
\hline Regulatory Quality - lag 1 & 34.47 & 7.20 & 4.79 & $0.00 * * *$ & 90.74 & 69.89 & 1.30 & 0.19 \\
\hline Rule of Law & -20.71 & 10.31 & -2.01 & $0.04 * *$ & -156.33 & 100.12 & -1.56 & 0.12 \\
\hline Rule of Law - lag 1 & 3.33 & 12.05 & 0.28 & 0.78 & -43.86 & 117.02 & -0.37 & 0.71 \\
\hline Control of Corruption & -38.43 & 13.00 & -2.96 & $0.00 * * *$ & 19.44 & 126.19 & 0.15 & 0.88 \\
\hline Control of Corruption - lag 1 & -5.62 & 9.95 & -0.56 & 0.57 & 29.12 & 96.56 & 0.30 & 0.76 \\
\hline & & & & & & atility & & \\
\hline & & & $\mathrm{Co}$ & & STD. & Tstat & & value \\
\hline Constant & & & 0.00 & & 0.00 & 1.15 & 0.25 & \\
\hline FDInet - lag 1 & & & 0.00 & & 0.00 & -3.37 & 0.00 & \\
\hline GDP - lag 1 & & & 0.00 & & 0.00 & -0.86 & 0.39 & \\
\hline LaborCost - lag 1 & & & 0.00 & & 0.00 & -0.05 & 0.96 & \\
\hline CDS - lag 1 & & & 0.00 & & 0.00 & 1.64 & 0.10 & \\
\hline Volatility - lag 1 & & & 0.51 & & 0.07 & 6.94 & 0.00 & \\
\hline Exogenous & & & & & & & & \\
\hline Voice and Accountability & & & 0.00 & & 0.00 & 0.21 & 0.83 & \\
\hline Voice and Accountability - la & & & 0.00 & & 0.00 & -1.15 & 0.25 & \\
\hline Political Stability No Violenc & & & 0.00 & & 0.00 & -0.90 & 0.37 & \\
\hline Political Stability No Violenc & - lag 1 & & 0.00 & & 0.00 & -0.51 & 0.61 & \\
\hline Government Effectiveness & & & 0.00 & & 0.00 & 0.47 & 0.64 & \\
\hline Government Effectiveness - la & & & 0.00 & & 0.00 & 0.81 & 0.42 & \\
\hline Regulatory Quality & & & 0.00 & & 0.00 & 0.35 & 0.73 & \\
\hline Regulatory Quality - lag 1 & & & 0.00 & & 0.00 & 1.04 & 0.30 & \\
\hline Rule of Law & & & 0.00 & & 0.00 & -0.16 & 0.88 & \\
\hline Rule of Law - lag 1 & & & 0.00 & & 0.00 & 0.27 & 0.78 & \\
\hline Control of Corruption & & & 0.00 & & 0.00 & 0.80 & 0.42 & \\
\hline Control of Corruption - lag 1 & & & 0.00 & & 0.00 & -1.35 & 0.18 & \\
\hline
\end{tabular}


Our results confirm the effect of GDP and labour cost on Net FDI that were also identified previously by other authors.

Adding to that, we also found that CDS have a statistically significant influence, thus complementing the previous findings of other author that document the influence of credit ratings on net FDI. From an economic point of view this is explained by the fact that both credit ratings and CDS reflect perceptions of outside investors and analysts on the credit risk of the public sector, which is also linked with the credit risk of the whole economy, so in the end both indicators are indirectly reflecting also perceptions towards the entire economy including the private sector.

Among the exogenous and more qualitative variables included in the VAR analysis our results show a statistically significant influence on FDI from Voice and Accountability, Government Effectiveness, Regulatory Quality and Control of Corruption. In our opinion these results identify the main concerns that foreign investors focus upon when choosing to allocate a long term direct investment in a developing economy, at least in the European area.

From our results, most of the above identified factors manifest their influence with one lag, on annual data, which in our interpretation is reflecting the long-term approach that investors have and the consistent time delay that usually and necessary exists between the change in their sentiment / perceptions and the change in their investment decisions.

\section{Conclusions}

In this paper we investigated the impact on FDI of different qualitative and quantitative factors. We included in our study 10 European countries with developing economies and we based our analysis on quarterly and annual data regarding economic variables (GDP, labour cost), market variables reflecting country risk perception (equity markets volatility, CDS), economic sentiment indicators (various sentiment and confidence indices computed by the European Commission) and perception indicators reflecting the "ease of doing business" (various measures of transparency, public sector governance and accountability, political stability, law enforcement and control of corruption computed by the World Bank).

Our aim was to include in the analysis a dual approach on multiple layers. Thus, on the one hand we wanted to reflect the views on the economy both by internal agents (via the sentiment and confidence indicators of consumers and managers within industry and services sectors computed by the European Commission) and by foreign investors. Consolidating our dual approach, the factors regarding the view of the foreign investors were reflected both via market indicators such as volatility and CDS prices and also using World Bank indices regarding the country situation regarding political stability, government and supervisory effectiveness and rule of law.

On the second hand we wanted to include both a long term and a short term approach, by using indicators both on quarterly and annual frequency and by considering both contemporaneous values also lagged values in the equations of the tested equations.

Also, our objective was to extend the research towards more qualitative possible determinants of FDI, reflecting the characteristics of the government, supervisory framework and judicial system that influence decision of foreign investors. 
Sentiment, Perception and Policy Determinants of Foreign Direct Investment to European Developing Countries

We have employed a stepwise panel regression approach including all the variables mentioned above, at quarterly and annual frequency and a one-lag panel VAR for the variables at annual frequency.

The results that we have obtained from the panel regression on the quarterly data we notice that factors with statistical significant influence on FDI are encountered only in very isolated situations, with Economic Sentiment and CDS providing most significant coefficients.

Our results on the annual data panel regressions reveals more factors with statistically significant contributions to FDI, especially in the case of the Fixed Effects in levels and the Random Effects in differences. We can also conclude that Voice and Accountability and Rule of Law show situations with a statistically significant influence on FDI.

The results from our VAR model on annual data confirm the effect of GDP and labour cost on Net FDI that were also identified previously by other authors. We also found a statistically significant influence from CDS prices, which is aligned with previous findings of other author on the influence of credit ratings.

The VAR analysis that we have employed showed a statistically significant influence on FDI from Voice and Accountability, Government Effectiveness, Regulatory Quality and Control of Corruption which in our view identifies some of the main qualitative concerns that foreign investors have when taking investment decisions towards a developing economy in the European area.

The analysis of the factors affecting the FDI can be further developed using a Mixeddata sampling (MIDAS) approach that could have the benefit of including in the same model variables at different frequencies, but this will only be possible as more data points will become available since some of the quarterly indicators are only published more recently.

\section{REFERENCES}

[1] Asghar, N., Nasreen, S. and Rehman, H. (2012), Relationship between FDI and Economic Growth in Selected Asian Countries: A Panel Data Analysis. Review of Economics and Finance, 2, 84-96;

[2] Aydin, N. and Zortuk, M. (2014), Measuring Efficiency of Foreign Direct Investment in Selected Transition Economies with a Fuzzy Data Envelopment Analysis. Economic Computation and Economic Cybernetics Studies and Research, 48(3), 235-248;

[3] Baklouti, N. and Boujelbene, Y. (2016), Foreign Direct Investment-Economic Growth Nexus. Acta Universitatis Danubius, 12(2), 136-145;

[4] Birsan, M. and Buiga, A. (2009), FDI Determinants: Case of Romania. Transition Studies Review, 15, 726-736;

[5] Daude, C. and Stein, E. (2007), The Quality of Institutions and Foreign Direct Investment. Economics and Politics, 19(3), 317-344;

[6] Delgado, M.S and McCloud, N. (2017), Foreign Direct Investment and the Domestic Capital Stock: The Good-Bad Role of Higher Institutional Quality. Empirical Economies, 53, 1587-1637; 
Leonardo Badea, Iulian Panait, Adela Socol, Andreea Daniela Moraru

[7] Gangi, Y.A. and Abdulrazak, R.S. (2012), The Impact of Governance on FDI Flows to African Countries. World Journal of Entrepreneurship, Management and Sustainable Development, 8(2/3), 162-169;

[8] Kaufmann, D., Kraay, A., Pablo Z.L. (1999), Governance Matters. World Bank Policy Research Working Paper 2196, Washington, DC;

[9] Kiyota, K. and Urata, S. (2004), Exchange Rate, Exchange Rate Volatility and Foreign Direct Investment. The World Economy, 27(10), 1501-1536;

[10] Kurecic, P. and Kokotovic, F. (2017), The Relevance of Political Stability on FDI: A VAR Analysis and ARDL Models for Selected Small. Developed, and Instability Threatened Economies. Economies, 5(3), 1-21;

[11] Labes, S.A. (2015), FDI Determinants in BRICS. CES Working Papers, 2, 296-308;

[12] Mutascu, M.I. and Fleischer A.M. (2010), A VAR Analysis of FDI and Wages: The Romania's Case. International Journal of Economic Sciences and Applied Research, 3(2), 41-56;

[13] Organisation for Economic Co-operation and Development OECD (1996).

Benchmark Definition of Foreign Direct Investment, accessed at 11.02.2018, available online at https://archive.org/details/bub_gb_brjncJGuEyAC;

[14] Simionescu, M. (2014), The Relationship between Trade and Foreign Direct Investment in G7 Countries a Panel Data Approach. Journal of Economics and Development Studies, 2(2), 447-454;

[15] Simionescu, M. (2016), The Relation between Economic Growth and Foreign Direct Investment during the Economic Crisis in the European Union. Zbornik radova Ekonomskog fakulteta u Rijeci, časopis za ekonomsku teoriju i praksu - Proceedings of Rijeka Faculty of Economics. Journal of Economics and Business, 34(1), 187-213;

[16] Simionescu, M.D. (2017), Determinants of Foreign Direct Investments in Bulgaria and Romania in the Context of Recent Economic Crisis. Academic Journal of Economic Studies, 1, 68-72;

[17] Wang, T.L. and Hung-Pin, L. (2017), Causality on Outward Foreign Direct Investment and Domestic Investment in Newly Industrialized Asian Countries. Economic Computation and Economic Cybernetics Studies and Research; ASE Publishing, 51(2), 267-280.

\section{Appendix 1 - Distribution of p-values for all specifications}

Percentile of p-values for Fixed Effects, Levels, Quarterly

\begin{tabular}{lrrrrr} 
Percentile & 10 & 20 & 30 & 40 & 50 \\
\hline Ec. Sent. & $53.5 \%$ & $59.8 \%$ & $66.8 \%$ & $74.6 \%$ & $80.2 \%$ \\
Ind. Confid. & $44.3 \%$ & $54.9 \%$ & $61.0 \%$ & $69.9 \%$ & $75.4 \%$ \\
Serv. Confid. & $38.5 \%$ & $50.7 \%$ & $55.4 \%$ & $60.3 \%$ & $74.0 \%$ \\
Cons. Confid. & $41.6 \%$ & $51.6 \%$ & $57.0 \%$ & $67.2 \%$ & $76.1 \%$ \\
GDP & $24.2 \%$ & $38.9 \%$ & $53.3 \%$ & $58.5 \%$ & $65.7 \%$ \\
Labor Cost & $28.8 \%$ & $47.5 \%$ & $55.3 \%$ & $65.1 \%$ & $74.5 \%$ \\
CDS & $31.0 \%$ & $42.7 \%$ & $53.8 \%$ & $59.4 \%$ & $67.0 \%$ \\
Volatility & $30.2 \%$ & $45.4 \%$ & $53.9 \%$ & $59.7 \%$ & $67.2 \%$
\end{tabular}


Sentiment, Perception and Policy Determinants of Foreign Direct Investment to European Developing Countries

Percentile of p-values for Robust Fixed Effects, Levels, Quarterly

\begin{tabular}{lrrrrr} 
Percentile & 10 & 20 & 30 & 40 & 50 \\
\hline Ec. Sent. & $13.6 \%$ & $37.7 \%$ & $44.8 \%$ & $52.5 \%$ & $58.3 \%$ \\
Ind. Confid. & $28.7 \%$ & $46.2 \%$ & $50.2 \%$ & $54.0 \%$ & $58.4 \%$ \\
Serv. Confid. & $37.6 \%$ & $42.5 \%$ & $46.0 \%$ & $49.1 \%$ & $54.0 \%$ \\
Cons. Confid. & $13.6 \%$ & $24.7 \%$ & $37.4 \%$ & $47.8 \%$ & $54.6 \%$ \\
GDP & $25.0 \%$ & $37.9 \%$ & $40.4 \%$ & $46.2 \%$ & $51.0 \%$ \\
Labor Cost & $14.6 \%$ & $35.4 \%$ & $39.9 \%$ & $47.9 \%$ & $58.3 \%$ \\
CDS & $25.1 \%$ & $38.8 \%$ & $43.6 \%$ & $48.7 \%$ & $52.5 \%$ \\
Volatility & $25.0 \%$ & $38.0 \%$ & $43.6 \%$ & $48.1 \%$ & $51.4 \%$
\end{tabular}

Percentile of p-values for Random Effects, Levels, Quarterly

\begin{tabular}{lrrrrr} 
Percentile & 10 & 20 & 30 & 40 & 50 \\
\hline Ec. Sent. & $53.5 \%$ & $62.2 \%$ & $68.2 \%$ & $71.6 \%$ & $75.1 \%$ \\
Ind. Confid. & $47.2 \%$ & $55.1 \%$ & $64.5 \%$ & $71.1 \%$ & $76.1 \%$ \\
Serv. Confid. & $33.6 \%$ & $40.6 \%$ & $47.5 \%$ & $54.1 \%$ & $60.3 \%$ \\
Cons. Confid. & $32.8 \%$ & $41.8 \%$ & $51.8 \%$ & $57.3 \%$ & $63.1 \%$ \\
GDP & $27.3 \%$ & $37.8 \%$ & $53.2 \%$ & $59.6 \%$ & $64.9 \%$ \\
Labor Cost & $25.1 \%$ & $35.2 \%$ & $47.2 \%$ & $61.5 \%$ & $69.7 \%$ \\
CDS & $27.3 \%$ & $43.1 \%$ & $52.7 \%$ & $61.4 \%$ & $68.8 \%$ \\
Volatility & $27.8 \%$ & $40.7 \%$ & $53.8 \%$ & $60.5 \%$ & $68.4 \%$
\end{tabular}

Percentile of p-values for Random Effects, Differences, Quarterly

\begin{tabular}{lrrrrr} 
Percentile & 10 & 20 & 30 & 40 & 50 \\
\hline Ec. Sent. & $6.7 \%$ & $8.6 \%$ & $11.2 \%$ & $14.2 \%$ & $18.4 \%$ \\
Ind. Confid. & $8.2 \%$ & $13.2 \%$ & $20.6 \%$ & $27.4 \%$ & $36.4 \%$ \\
Serv. Confid. & $7.8 \%$ & $12.6 \%$ & $20.6 \%$ & $29.3 \%$ & $36.9 \%$ \\
Cons. Confid. & $8.6 \%$ & $13.3 \%$ & $19.5 \%$ & $25.1 \%$ & $30.7 \%$ \\
GDP & $7.4 \%$ & $12.4 \%$ & $20.0 \%$ & $24.9 \%$ & $33.3 \%$ \\
Labor Cost & $7.3 \%$ & $11.1 \%$ & $18.2 \%$ & $24.0 \%$ & $31.9 \%$ \\
CDS & $7.4 \%$ & $10.4 \%$ & $18.3 \%$ & $22.6 \%$ & $30.4 \%$ \\
Volatility & $9.0 \%$ & $13.7 \%$ & $19.6 \%$ & $25.8 \%$ & $34.2 \%$
\end{tabular}

Percentile of p-values for Random Effects, Differences, Quarterly

\begin{tabular}{lrrrrr} 
Percentile & 10 & 20 & 30 & 40 & 50 \\
\hline Ec. Sent. & $5.1 \%$ & $6.2 \%$ & $7.6 \%$ & $8.8 \%$ & $9.9 \%$ \\
Ind. Confid. & $5.8 \%$ & $8.3 \%$ & $10.9 \%$ & $14.4 \%$ & $21.6 \%$ \\
Serv. Confid. & $5.9 \%$ & $8.5 \%$ & $10.8 \%$ & $14.8 \%$ & $23.1 \%$
\end{tabular}


Leonardo Badea, Iulian Panait, Adela Socol, Andreea Daniela Moraru

\begin{tabular}{lrrrrr}
\hline Cons. Confid. & $6.0 \%$ & $8.3 \%$ & $10.3 \%$ & $12.6 \%$ & $19.2 \%$ \\
GDP & $5.4 \%$ & $7.7 \%$ & $10.1 \%$ & $13.4 \%$ & $21.2 \%$ \\
Labor Cost & $5.2 \%$ & $7.5 \%$ & $9.6 \%$ & $12.4 \%$ & $18.2 \%$ \\
CDS & $5.5 \%$ & $7.2 \%$ & $8.8 \%$ & $10.9 \%$ & $16.4 \%$ \\
Volatility & $6.3 \%$ & $8.6 \%$ & $10.8 \%$ & $13.4 \%$ & $19.2 \%$
\end{tabular}

Percentile of p-values for Fixed Effects, Levels, Annually

\begin{tabular}{lrrrrr} 
Percentile & 10 & 20 & 30 & 40 & 50 \\
\hline Voice and Accountability & $0.2 \%$ & $0.3 \%$ & $0.4 \%$ & $0.5 \%$ & $0.9 \%$ \\
Political Stability No Violence & $0.3 \%$ & $0.6 \%$ & $1.9 \%$ & $6.2 \%$ & $10.5 \%$ \\
Government Effectiveness & $0.3 \%$ & $0.5 \%$ & $1.1 \%$ & $2.4 \%$ & $6.0 \%$ \\
Regulatory Quality & $0.2 \%$ & $0.4 \%$ & $1.3 \%$ & $3.4 \%$ & $8.0 \%$ \\
Rule of Law & $0.2 \%$ & $0.3 \%$ & $0.4 \%$ & $0.6 \%$ & $4.9 \%$ \\
Control of Corruption & $0.2 \%$ & $0.5 \%$ & $1.9 \%$ & $5.5 \%$ & $8.4 \%$ \\
GDP & $0.3 \%$ & $0.6 \%$ & $1.9 \%$ & $6.4 \%$ & $11.1 \%$ \\
Labor Cost Index & $0.2 \%$ & $0.5 \%$ & $2.0 \%$ & $5.8 \%$ & $10.9 \%$ \\
CDS & $0.2 \%$ & $0.5 \%$ & $1.6 \%$ & $5.2 \%$ & $8.5 \%$ \\
Volatility of USD & $0.3 \%$ & $0.5 \%$ & $1.5 \%$ & $5.3 \%$ & $10.0 \%$
\end{tabular}

Percentile of p-values for Robust Fixed Effects, Levels, Annually

\begin{tabular}{lrrrrr} 
Percentile & 10 & 20 & 30 & 40 & 50 \\
\hline Voice and Accountability & $4.4 \%$ & $5.9 \%$ & $7.4 \%$ & $9.6 \%$ & $11.7 \%$ \\
Political Stability No Violence & $6.0 \%$ & $8.8 \%$ & $11.3 \%$ & $13.5 \%$ & $16.9 \%$ \\
Government Effectiveness & $4.5 \%$ & $6.6 \%$ & $9.0 \%$ & $11.4 \%$ & $13.1 \%$ \\
Regulatory Quality & $4.5 \%$ & $6.9 \%$ & $9.5 \%$ & $12.3 \%$ & $15.4 \%$ \\
Rule of Law & $4.3 \%$ & $5.9 \%$ & $7.5 \%$ & $10.1 \%$ & $12.4 \%$ \\
Control of Corruption & $4.2 \%$ & $6.8 \%$ & $9.5 \%$ & $12.3 \%$ & $15.5 \%$ \\
GDP & $7.7 \%$ & $10.8 \%$ & $12.6 \%$ & $16.6 \%$ & $20.8 \%$ \\
Labor Cost Index & $4.8 \%$ & $8.1 \%$ & $11.4 \%$ & $14.4 \%$ & $17.8 \%$ \\
CDS & $5.0 \%$ & $7.4 \%$ & $10.1 \%$ & $12.5 \%$ & $15.4 \%$ \\
Volatility of USD & $5.2 \%$ & $8.7 \%$ & $11.8 \%$ & $14.8 \%$ & $17.6 \%$
\end{tabular}

Percentile of p-values for Random Effects, Levels, Annually

\begin{tabular}{lrrrrr} 
Percentile & 10 & 20 & 30 & 40 & 50 \\
\hline Voice and Accountability & $0.7 \%$ & $1.1 \%$ & $1.5 \%$ & $2.1 \%$ & $2.9 \%$ \\
Political Stability No Violence & $1.3 \%$ & $2.0 \%$ & $3.4 \%$ & $5.1 \%$ & $7.6 \%$ \\
Government Effectiveness & $0.8 \%$ & $1.2 \%$ & $1.7 \%$ & $2.6 \%$ & $4.1 \%$ \\
Regulatory Quality & $0.8 \%$ & $1.4 \%$ & $2.2 \%$ & $4.3 \%$ & $7.7 \%$ \\
Rule of Law & $0.9 \%$ & $1.5 \%$ & $2.6 \%$ & $3.9 \%$ & $6.4 \%$
\end{tabular}


Sentiment, Perception and Policy Determinants of Foreign Direct Investment to European Developing Countries

\begin{tabular}{lrrrrr}
\hline Control of Corruption & $0.9 \%$ & $1.5 \%$ & $2.6 \%$ & $4.4 \%$ & $7.2 \%$ \\
GDP & $1.2 \%$ & $2.0 \%$ & $3.3 \%$ & $6.0 \%$ & $14.7 \%$ \\
Labor Cost Index & $1.2 \%$ & $2.0 \%$ & $3.1 \%$ & $5.1 \%$ & $8.7 \%$ \\
CDS & $1.4 \%$ & $2.4 \%$ & $4.0 \%$ & $6.2 \%$ & $10.2 \%$ \\
Volatility of USD & $1.0 \%$ & $1.8 \%$ & $3.2 \%$ & $4.9 \%$ & $8.7 \%$
\end{tabular}

Percentile of p-values for Random Effects, Differences, Annually

\begin{tabular}{lrrrrr} 
Percentile & 10 & 20 & 30 & 40 & 50 \\
\hline Voice and Accountability & $0.1 \%$ & $0.1 \%$ & $0.2 \%$ & $0.3 \%$ & $0.3 \%$ \\
Political Stability No Violence & $0.1 \%$ & $0.3 \%$ & $0.4 \%$ & $0.6 \%$ & $12.6 \%$ \\
Government Effectiveness & $0.1 \%$ & $0.3 \%$ & $0.5 \%$ & $0.9 \%$ & $7.3 \%$ \\
Regulatory Quality & $0.1 \%$ & $0.2 \%$ & $0.3 \%$ & $0.5 \%$ & $6.6 \%$ \\
Rule of Law & $0.1 \%$ & $0.2 \%$ & $0.3 \%$ & $0.5 \%$ & $4.0 \%$ \\
Control of Corruption & $0.2 \%$ & $0.4 \%$ & $0.5 \%$ & $0.9 \%$ & $6.5 \%$ \\
GDP & $0.1 \%$ & $0.1 \%$ & $0.2 \%$ & $0.3 \%$ & $0.8 \%$ \\
Labor Cost Index & $0.1 \%$ & $0.2 \%$ & $0.4 \%$ & $0.7 \%$ & $6.7 \%$ \\
CDS & $0.1 \%$ & $0.2 \%$ & $0.4 \%$ & $0.7 \%$ & $7.2 \%$ \\
Volatility of USD & $0.1 \%$ & $0.2 \%$ & $0.4 \%$ & $0.7 \%$ & $6.3 \%$
\end{tabular}

Percentile of p-values for Random Effects, Differences, Annually

\begin{tabular}{lrrrrr} 
Percentile & 10 & 20 & 30 & 40 & 50 \\
\hline Voice and Accountability & $0.1 \%$ & $0.1 \%$ & $0.2 \%$ & $0.2 \%$ & $0.3 \%$ \\
Political Stability No Violence & $0.1 \%$ & $0.3 \%$ & $0.4 \%$ & $0.6 \%$ & $12.6 \%$ \\
Government Effectiveness & $0.1 \%$ & $0.3 \%$ & $0.5 \%$ & $0.9 \%$ & $7.3 \%$ \\
Regulatory Quality & $0.1 \%$ & $0.2 \%$ & $0.3 \%$ & $0.5 \%$ & $6.6 \%$ \\
Rule of Law & $0.1 \%$ & $0.2 \%$ & $0.3 \%$ & $0.5 \%$ & $4.0 \%$ \\
Control of Corruption & $0.2 \%$ & $0.4 \%$ & $0.5 \%$ & $0.9 \%$ & $6.5 \%$ \\
GDP & $0.1 \%$ & $0.1 \%$ & $0.2 \%$ & $0.3 \%$ & $0.8 \%$ \\
Labor Cost Index & $0.1 \%$ & $0.2 \%$ & $0.4 \%$ & $0.7 \%$ & $6.7 \%$ \\
CDS & $0.1 \%$ & $0.2 \%$ & $0.4 \%$ & $0.7 \%$ & $7.2 \%$ \\
Volatility of USD & $0.1 \%$ & $0.2 \%$ & $0.4 \%$ & $0.7 \%$ & $6.3 \%$
\end{tabular}

